DEMOGRAPHIC RESEARCH

VOLUME 31, ARTICLE 35, PAGES 1079-1106

PUBLISHED 12 NOVEMBER 2014

http://www.demographic-research.org/Volumes/Vol31/35/

DOI: 10.4054/DemRes.2014.31.35

Research Article

\title{
Religion and union formation in Italy: Catholic precepts, social pressure, and tradition
}

\section{Daniele Vignoli}

\section{Silvana Salvini}

This publication is part of the Special Collection on "Focus on Partnerships: Discourses on cohabitation and marriage throughout Europe and Australia," organized by Guest Editors Brienna Perelli-Harris and Laura Bernardi.

(C) 2014 Daniele Vignoli \& Silvana Salvini.

This open-access work is published under the terms of the Creative Commons Attribution NonCommercial License 2.0 Germany, which permits use, reproduction \& distribution in any medium for non-commercial purposes, provided the original author(s) and source are given credit.

See http:// creativecommons.org/licenses/by-nc/2.0/de/ 


\section{Table of Contents}

1 Introduction 1080

$2 \quad$ Religion and union formation choices: three potential contexts of 1082 interaction

$3 \quad$ Religion and the setting for family choices in Italy 1084

$4 \quad$ Data and method 1087

$5 \quad$ Results: Religion and union formation choices in Italy 1089

5.1 References to religion 1089

$\begin{array}{lll}5.2 & \text { Social pressure } & 1091\end{array}$

$\begin{array}{lll}5.3 & \text { Tradition } & 1093\end{array}$

$\begin{array}{lll}5.4 & \text { Within-country idiosyncrasies } & 1094\end{array}$

6 Results: Legal framework and union formation choices 1095

$\begin{array}{lll}7 & \text { Summary and discussion } & 1097\end{array}$

8 Acknowledgements 1099

$\begin{array}{ll}\text { References } & 1100\end{array}$ 


\title{
Religion and union formation in Italy: Catholic precepts, social pressure, and tradition
}

\author{
Daniele Vignoli $^{1}$ \\ Silvana Salvini ${ }^{2}$
}

\begin{abstract}
BACKGROUND

Italy is customarily viewed as a traditional Catholic country. At the same time, couples are increasingly living together without marrying. Establishing links between religion and family formation is a complex issue and little is known about specific mechanisms through which religion shapes family change in the country.
\end{abstract}

\section{OBJECTIVE}

We aim to shed light on which aspects of religion are important in decisions about family formation.

\section{METHODS}

We analyze data from eight focus group interviews conducted in Florence. In the transcripts we identify any references to religion and systematically compare categories to investigate how religiosity intertwines with relationship choices. We apply bottomup coding procedures to identify meaning and concepts within three theoretically relevant areas: Catholic precepts, social pressure, and tradition.

\section{RESULTS}

Despite the predominance of religion in the studied setting, Italians behave without according much importance to Catholic precepts and dogmas. Religion seems to influence people's family behaviors through social pressures to marry generated by the family of origin and the judgment of 'others'. Tradition also plays an important role.

\section{CONCLUSIONS}

The widely prevailing pressure of parents and peers and the hedonistic aspects of the traditional Church wedding seem to be more important in partnership formation than Catholic prescripts. Thus, we posit that the direct effect of religion on individual choices is overestimated when interpreting the Italian family. In addition, we note the

\footnotetext{
${ }^{1}$ University of Florence, Italy. E-Mail: vignoli@disia.unifi.it.

${ }^{2}$ University of Florence, Italy.
} 
divergence that exists between the lack of state laws concerning consensual unions and the acceptance of cohabitation on an individual basis.

\section{Introduction}

The literature supporting the idea of the "Second Demographic Transition" advocates that changes in family behaviors in the Western World have been strongly linked to secularization $^{3}-$ a process characterized by the withdrawal from traditional religious beliefs and a decline in subjective religiosity among individuals (Lesthaeghe and Surkyn 1988; Van de Kaa 1987; Lesthaeghe and Neidert 2006). In this context Italy represents an interesting case study. Attachment to Catholic values and the strong position of the Roman Catholic Church constitute key elements that characterize Italian society. Pre-marital sex, cohabitation, and divorce are forbidden by the Church, whereas a high value is placed on marriage and family life. In addition, the presence of the Vatican City within the national borders makes Italy a unique setting for studying the links between religion and family choices. Italian demographers and sociologists have often linked the strong attachment to Catholic values to the delayed diffusion in Italy of new family behaviors such as cohabitation, marital dissolution, or non-marital childbearing (De Sandre et al. 1997; Barbagli and Saraceno 1997; Angeli, Pillati, and Rettaroli 1999; Castiglioni 1999; Barbagli 2000; Barbagli, Castiglioni and Dalla Zuanna 2003; De Rose, Racioppi, and Zanatta 2008; Zanatta 2008; De Rose and Vignoli 2011).

Despite its orientation towards placing a high value on traditional marriage, however, contemporary Italy is faced with a rising breakdown of marriages and a growing flexibility of union patterns. In less than 20 years, between 1993 and 2011, the number of cohabiting unions increased from 227,000 to 972,000 , and, among them, the number of unmarried partners increased from 67,000 to 578,000 (Istat 2011). In addition, the diffusion of cohabitation is no longer confined solely to certain social groups or to certain geographical areas (Gabrielli and Hoem 2010; Gabrielli and Vignoli 2013). Interestingly, the diffusion of cohabitation is developing hand in hand with a slow but continuous process of secularization (Sansonetti 2009). This trend towards greater secularization is suggested by the generalized decrease in participation in public religious practice and in particular in rites of passage (e.g., baptism,

\footnotetext{
${ }^{3}$ Secularization is a multidimensional and complex social process. In this paper we refer to secularization as an overall reduction in religious denomination and practice (for a general review of the concept see Gorski and Altınordu 2008; for a review of the concept with specific reference to Mediterranean Europe see Kosmin and Keysar 2009).
} 
communion, Church wedding), as well as by a decrease in religious vocations (Sansonetti 2009).

Overall, macro and micro empirical research illustrate a correlation between family-related behaviors and religiosity (e.g., Tanfer 1987; Adsera 2006; Frejka and Westoff 2008; Philipov and Berghammer 2007; Berghammer 2009; Berghammer 2012). Studies that tested the relationship between religiosity and family patterns found a strong and positive association between religious affiliation and commitment, and conventional sexual values and behavior (e.g., in the U.S.: Thornton and Camburn 1987; Sweet and Bumpass 1990; Thornton, Axinn, and Hill 1992; in the Netherlands: Liefbroer and Gierveld 1993). For Italy, Löffler (2009) revealed that women with little or no Roman Catholic Church affiliation enter cohabitation more often than do other women. Religious people, especially those who are religiously active, are less likely to cohabit than secular people (Löffler 2009). While these quantitative studies demonstrate a relationship between religion and family behaviors, they have limited power in informing us of how people think about the relationship between religion and union formation, specifically the extent to which individuals see religion influencing their choices. A recent study explicitly addressed the role of people's perceptions of religious influence on their family decisions (Sigalow, Shain, and Bergey 2012). The authors urged future research to investigate the role that religion plays in family life in order to understand "if and how people use religion as a guide in their lives and in what contexts people draw upon religion" (Sigalow, Shain, and Bergey 2012: 321).

This paper addresses the role of religion on union formation through qualitative research. By drawing upon data from eight Focus Group (FG) interviews conducted in Florence we aim to shed light on which aspects of the overall influence of religion on family formation choices are the most important. Florence is a typical secular city of the Central-Northern Italian region, governed since the 1980s by liberal left-wing parties that are relatively supportive of non-traditional living arrangements. Thus, this setting is important for showing the role of religion in union formation when a society is undergoing secularization and a redefinition of being religious among its citizens. The FG transcripts were systematically scrutinized in order to explore three key potential mechanisms through which religion may act: (1) the role of Catholic precepts, (2) the role of social pressure, and (3) the role of tradition. We move beyond past research by parsing out how people perceive religion in connection with their family choices. In addition, we contribute to the overall understanding of the role of religion in the everyday life of Italians.

This study also has an important ancillary objective. Given the recent increase in the number of people choosing to live together without marrying in Italy - especially as a prelude to marriage - we intend to provide qualitative evidence of the paradox that 
exists between the lack of state laws towards consensual unions (in terms of partners' rights and obligations) and the practice of cohabitation on an individual basis.

The rest of the paper proceeds as follows. Section 2 discusses the role of religion in driving the adoption of new family patterns, proposing three major channels through which religion may act. Section 3 presents the context of and main trends in family formation practices in Italy. Data, method, and results follow (Section 4 and 5). The last Section 6 concludes the paper with a summary and discussion of the main findings.

\section{Religion and union formation choices: three potential contexts of interaction}

A large literature has established a connection between religion and family behavior (e.g., Thornton, Axinn, and Hill 1992; Lehrer 2000; Teachman 2002; McQuillan 2004; Adsera 2006; Frejka and Westoff 2008; Berghammer 2009, 2012). Various dimensions of religiosity, including attendance, commitment, and the centrality of religion in people's lives, have been shown to be associated with many dimensions of family life such as marriage, divorce, and family size. While quantitative studies have provided important insights into the link between secularization and family formation practices on the population level, they have been unable to shed light on specific mechanisms through which religiosity and secularization intertwine with relationship choices. In this section we discuss three potential contexts of interaction between religion and union formation: (1) Catholic precepts, (2) social pressure, and (3) tradition.

First, marriage and sexual relations are interwoven in the moral teachings and precepts of most religions (Thornton, Axinn, and Hill 1992). Historically, strong ties exist between religion and conventional family lifestyles (Oropesa 1996). Since the Late Middle Ages the Catholic Church has held the Christian sacrament of marriage to be the sole base of intimate relationships and human reproduction. According to the Catholic doctrine, sexual intercourse is only appropriate in the context of marriage, because only in marriage can sexuality express the two fundamental dimensions of conjugal life: the harmony and fertility of the couple. In Catholic morality premarital sexual relations are not only disapproved of: they are simply excluded. Hence, Catholic people should opt for marriage rather than cohabitation. Those who wish to marry have to agree on the times and the dynamics of their marriage preparation, grow in intimacy, and preserve the most complete expression of their love for the future conjugal life. Catholic principles thus dictate a sharp transition from the family of origin to the family of procreation, which leaves little (or no) space for cohabitation. Importantly, religions that rely on a hierarchically organized church and which are dominant throughout a country (as is the case for the Roman Catholic Church in Italy) should face weaker 
discrepancies between official dogmas and the local teachings and practices of Church officials (Ellingson et al. 2001).

Second, individuals may experience social pressure to marry. Religiosity may not only impact individual-level behavior by promoting specific norms or rules, it may also promote broader values or principles that impact family formation indirectly (McQuillan 2004; Goldscheider 2006). Those who marry exhibit socially accepted behavior and receive approval from society, family, and individuals in their social surroundings (Kalmijn 2004). This could be of particular importance in countries where cohabitation is less accepted, such as Southern Europe (and Italy). According to Reher (1998), Mediterranean countries are characterized by strong family ties, with Catholicism contributing to the continuation of traditional family structures. Dalla Zuanna (2001) described the relationship between Roman Catholic belief and prevailing family patterns: he suggested that Catholicism has reinforced familism, and vice versa (see also Dalla Zuanna and Micheli 2004). Thus, parents may be especially important in influencing the choice of whether to cohabit or marry. Young people follow their parents' religious denomination and frequently follow their parents' levels of religious commitment and participation (Löffler 2009). In addition, parents can influence the perceptions and behaviors of their children through their guidance and supervision. For instance, Rosina and Fraboni (2004) suggest that in Italy young adults weigh the decision to adopt a new living arrangement with the level of acceptance of their family of origin. Parents view the failure of their children as their own failure and they may try to discourage their offspring from doing things that are socially uncommon or not accepted (Di Giulio and Rosina 2007), such as behaving counter to the prevailing Catholic doctrine.

Besides the judgment of the family of origin, the neighborhood may also influence the choice to cohabit or to marry. Those living in religious surroundings are likely to be embedded in very specific types of social networks that maintain behavior that is consistent with the prescription of the dominant religion (Smith 2003). Neighborhoodlevel religiosity may interact with individual religiosity or moderate its effect. The lack of social acceptance for non-marital cohabitation imposed in certain surroundings may restrict individual decisions regarding family formation, even of non-religious people (Baranowska-Rataj, Mynarska, and Vignoli 2013). Altogether, the choice to cohabit is linked with heavier psychological costs than the choice to marry, especially for religious people, because of a generalized social disapproval of cohabitation stemming from both the family of origin and the network of people individuals are confronted with.

Third, an important context in which religion interacts with family formation lies in the power of tradition. The term tradition usually refers to the transmission over time of memories, social or historical events, customs, rituals, and religious beliefs within a 
group or society (e.g., family traditions). Giddens (1994) sees tradition as something bound to ritual, where ritual guarantees the continuation of tradition. Although the concept of tradition is clearly intertwined with familial and social pressure towards marriage, it allows us to explore the link between religion and union choices from a different angle. The Catholic Church maintains a strong influence in many societies, especially in Southern Europe, also in light of the prevailing tradition. Adult children must rely on prevailing customs and habits when making their own choices. From this perspective, many Catholics preserve religion merely as a form of social identity and tradition, going to church only for rites of passage (Pierucci and Prandi 2000). Marrying in Church is perhaps the most important of such rites (Dittgen 1995).

\section{Religion and the setting for family choices in Italy}

The Italian setting offers an intriguing forum for the exploration of the specific mechanisms that link religion and family formation dynamics. As in other Southern European societies, Italians are "shaped by the Church and hence strongly committed to the preservation of traditional familyhood" (Esping-Andersen 1990: 27). In Italy, the Catholic Church directly controls a national radio station (Vatican Radio, which is translated into 41 other languages), a satellite television channel (Sat 2000, owned by the Italian Episcopal Conference) and two national newspapers (L'Osservatore Romano, the official Vatican newspaper, also available in seven other languages, and L'Avvenire, the official newspaper of the Italian Episcopal Conference). Catholic organizations control other national mass media such as a national radio station (Radio Maria, which is quite diffused although mainly listened to by the elderly), magazines, and periodicals at national or local levels (among which it is worth mentioning Famiglia Cristiana, which is very widespread and represents an important channel of diffusion of family ideals). In addition, a large number of Catholic television and radio programs are broadcast weekly by all the channels of Italian state television and radio (Rai) (Sansonetti 2009). Today, the state provides public schools with church-appointed teachers of Catholic religion and pays the teachers' salaries (students or parents have to declare at the beginning of the school year whether they want to attend religion courses or not). In short, in Italy, as in many other countries, the 'institutional' presence of the Church in the everyday life of its citizens is not negligible. However, Catholicism is not monolithic, as many different attitudes towards the hierarchy, volunteering, the Holy Father, and several ethical issues coexist in the country (Garelli 2011; Bonarini 2013).

According to data from the International Social Survey Programme (2008), over 90\% of citizens in Italy are raised in the Catholic religion (compared with an average of $49 \%$ in other EU member states). In addition, $30 \%$ of Italians believe that religious 
leaders should try to influence the decisions of the government (Kosmin 2009). In order to contextualize what distinguishes Italy from other countries in the "domain" of religion, we refer to a recent study that proposed a method to evaluate the relative "distance" between countries based on individual data (De Santis, Maltagliati, and Salvini 2014). The authors applied the method ${ }^{4}$ to the World Value Survey (WVS) dataset for the years 1994-2007 on several "domains", including religion. In the WVS data there were seven elementary variables associated with the latent variable "religion" (for a list of the questions used, see De Santis, Maltagliati, and Salvini 2014). They then provide a rough approximation to measure how high or low each respondent scored on the latent dimension of religion, which was obtained by (arbitrarily) associating each answer with a numerical value ${ }^{5}$. The summary results suggest that, in the European context, Romania, Poland, and Italy (in that order) proved to be more religiously oriented than other countries.

The position of the Church has historically permeated the context of family choices in Italy. From the postwar period until the breakdown of the old political regime in 1992, Italy was led for almost half a century by governments of Catholic background $^{6}$. Catholicism maintained a strong influence on the public and private lives of Italians, especially in areas where the Catholic party Democrazia Cristiana had more than $50 \%$ of votes during the three decades following World War II: in some provinces of the North-East and in most provinces of the South (Dalla Zuanna, De Rose, and Racioppi 2005). During the leadership of these governments, however, Italy experienced a series of important changes in a very short time-span, mainly due to the political awakening of the young in the 1960s and the strength of the feminist movement in the 1970s (Livi Bacci 2001; De Rose, Racioppi, and Zanatta 2008). Divorce was introduced in 1970 (Law n. 898), although divorce can only occur after the couple is legally separated for a long period (initially five years; three years since 1987). In 1975, key improvements in Italian family law assigned the same rights to children born outside marriage as to those born within marriage, especially regarding the right of alimony. Previously, children born out of wedlock had suffered legal discrimination. Abortion was legalized in 1978. Both divorce and abortion laws were subsequently confirmed by referenda: 59\% of Italians voted for divorce in 1974 and $67 \%$ for abortion in $1981^{7}$.

\footnotetext{
${ }^{4}$ First, clusters of respondents are formed and the proportion of each country's respondents that belongs to the various clusters is calculated. Second, the distance between countries is expressed in terms of distance between the observed distributions (the average of the squared differences between the ranks).

${ }^{5}$ The attributed scores did not influence the results, however (De Santis, Maltagliati, Salvini 2014).

${ }^{6}$ For a review of the role played by the Church in the historical development of Italy see Ercolessi (2009).

${ }^{7}$ Italy was not alone in this process as the 1970s was a decade of change for many Western societies (e.g., in the US abortion was legalized in 1973, and in France and Germany in 1975).
} 
With the exception of a few minor regional laws, there are no legal regulations devoted to unmarried couples. Legal judgments are essentially made case-by-case on the basis of the partners' situation (Zanatta 2008). Cohabiting individuals have less protection in the case of a separation or partner's death because they do not have access to alimony or to the partner's old age pension. In addition, these legal judgments are complex, especially when unmarried partners split up after neglecting to specify who paid which amounts of money for what purpose. In 2007 a moderate government bill on the legal recognition of the rights and obligations of cohabiting (including same-sex) couples was abandoned, due to controversies inside the "center-left" parliamentary majority (De Rose and Marquette 2011).

Previous studies have advocated a strong link between religion and family-related behaviors in Italy (Castiglioni 1999). Individuals who openly declare being in favor of cohabitation are generally those who are atheist or agnostic or, despite claiming to be religious, admit that they do not practice Catholic rites (Angeli, Pillati, and Rettaroli 1999). However, the link between Catholic precepts and individual behaviors is far more complex than simple predictions would suggest (Barbagli and Saraceno 1997). Surveys conducted in the middle class in the 1970s showed that attitudes were becoming more flexible when applying Catholic precepts (e.g., in terms of pre-nuptial sexual behavior and contraception), as well as a growing detachment towards these precepts (De Sandre et al. 1997). In addition, during the early 1970s the incidence of non-religious marriages (among all marriages) increased from 2\% to 10\%: nowadays almost $40 \%$ of marriages are celebrated with a civil ceremony. A civil marriage clearly represents a secularized choice, displayed to the outside world (Impicciatore and Billari 2012). In parallel, another tangible sign of secularization is represented by the decline in public religious practices. Participation in life-cycle rites decreased in Italy during 1991-2004. Of the total children born alive in a year, the percentage of children under age one who were baptized fell from $89.9 \%$ in 1991 to $77.5 \%$ in 2004 (Sansonetti 2009). This decline may be related not only to the increasing presence of foreign people but also to a new attitude of Italian parents towards baptism (Bonarini 2013).

Up to the second half of the 1970s, family patterns in Italy were characterized by very rigid life courses, with marriage at the center; then traces of change began to emerge. Marriage rates declined slightly, while cohabitation and marital dissolution spread throughout the population. These changes intensified in the 1990s and spiked in the first decade of the twenty-first century, when the pace of change rose dramatically (Vignoli, Gabrielli, and Gualtieri 2011). Marriage is now increasingly postponed (in the period 2000-2008 the mean age at first marriage rose from 28 to 30 years for women and from 31 to 33 years for men). This phenomenon explains most of the reduction in crude marriage rates, from 6 per thousand in 1990 to 5 per thousand in 2000 and up to 4 per thousand in 2008. In the period 2006-2009, 38\% of couples opted for cohabitation 
as their first type of union (own computations on 2009 Family and Social Subjects survey). The diffusion of cohabitation has contributed to the rise of non-marital births: in 2010 non-marital births were over 134,000 , nearly a quarter of total births. The increase was rapid: from $2 \%$ in 1970 to $10 \%$ in 2000 , to $19 \%$ in 2008 , to $20 \%$ in 2009 , and up to $24 \%$ in 2010 . The general downward trend in marriage and upward trend in cohabitation is a widespread phenomenon in Italy, but regional differentials persist. People marry more in the South (4.9 per thousand inhabitants in 2008) than in the North (3.6 per thousand inhabitants) and Central Italy (4 per thousand inhabitants). Also the recent increase in consensual unions appears mainly in Northern and Central Italy and not in the South, where non-marital unions remain quite rare (Gabrielli and Hoem 2010).

\section{Data and method}

We conducted FG interviews in February to April 2012 in Florence. A focus group is a small group of individuals, generally comprising 6-8 people, that discusses topics organized around a major theme, with the discussion guided by a moderator. The data for this research have been collected following the research design developed by the international research project, Focus on Partnerships. Team members collaborated to create a standardized focus group guideline, which was used to direct the focus group discussions. (For further information on this project see Perelli-Harris et al. (2014) or www.nonmarital.org.) The interview guidelines included numerous questions regarding cohabitation and marriage, such as the (dis)advantages of living together without marriage, motivations for marriage, and barriers to marriage. Marriage and cohabitation were also explored in relation to institutions, policies, and laws. Importantly for this paper, the role of religion was investigated using an explicit probing question.

Recruitment of the participants and organization of the focus group interviews were supported by the research agency, University of Florence Academic Spin-Off Valmon s.r.l., and the discussions took place at its premises. The research agency recruited via the distribution of brochures and advertisements in cinemas, universities, sport clubs, shopping malls, etc. The participants received an incentive of 20 euros per person. Participants were 25-40 years of age and were divided into groups by gender and educational attainment. In accordance with the project guidelines, focus groups were not stratified by partnership and parenthood status, because partnership histories can be inherently complicated, and it was unclear how to categorize those who experienced premarital cohabitation, separation or divorce, remarriage, etc. Hence, because our main goal was to gain deeper insight into the nature of cohabitation and 
marriage across different countries and not to explain individual biographies, we did not stratify by partnership and parenthood status.

The higher level of education included women and men with a bachelor's or a master's degree as well as those with a post-tertiary qualification. The lower level of education included primary, vocational, lower-secondary, and upper-secondary educational attainment. In total, eight FG interviews were conducted: two with women of low-medium education, two with women with some tertiary education, two with men of low-medium education, and two with men with tertiary degree. Those who worked in any kind of social research were excluded from the sampling strategy. Altogether 58 informants participated in the study. The overall composition of the sample is reported in Table 1.

Our analysis aimed to explore how people talked about cohabitation and marriage in relation to religion. Special attention was paid to any references to religiosity and secularization with respect to the pros and cons of cohabitation and marriage. Within this material we applied bottom-up coding within the three main contexts identified as theoretically important: (1) the role of Catholic precepts, (2) the role of social pressure, and (3) the role of tradition. We finally reached a set of categories within each of these three major themes. In addition, a systematic bottom-up exploration of FG interviews was made with the aim of studying the link between the lack of state laws towards consensual unions (in terms of partners' rights and obligations) and individual choices. Despite our sample not being representative of the population of young women and men in Florence, we are confident that our results offer a good representation of the range of meanings and attitudes attached to cohabitation and marriage in relation to religion.

Table 1: Structure of the sample by gender and education

\begin{tabular}{lcccccccc}
\hline Country sample & FG1 & FG2 & FG3 & FG4 & FG5 & FG6 & FG7 & FG8 \\
\hline Men & 9 & 8 & 7 & 8 & & 8 & & 5 \\
Women & 9 & 8 & 7 & 8 & & & 7 & \\
\hline $\begin{array}{l}\text { High Education } \\
\text { Low Education }\end{array}$ & & & & & 6 & 8 & 7 & 5 \\
\hline N. of participants & 9 & 8 & 7 & 8 & 6 & 8 & 7 & 5 \\
\hline
\end{tabular}

The main advantage of focus group methodology over individual in-depth interviews is that this method provides the opportunity to study people in a more natural conversation situation. For instance, a spontaneous debate among participants on the link between union formation choices and the legal framework led to inferences on 
some issues that were not included within the original guidelines (see Section 6). During the FG interviews there were some differences by gender and education in the way people reacted to the questions and in the overall atmosphere of the different meetings. First, the low-educated group, irrespective of gender, had difficulties in expressing concepts and making general statements. Men with lower education were the least talkative. By contrast, men and women with higher education talked more and made longer statements. Second, more disagreements and arguments occurred in higher educated groups. When a statement was made in the lower educated group it was harder for the other participants to argue against it. Finally, women, and especially those of low education, were more likely to make specific references to their own experiences (e.g., talking about their own life, or telling stories of friends and family) than men did. Women were also more likely to go off at a tangent.

\section{Results: Religion and union formation choices in Italy}

\subsection{References to religion}

A systematic analysis of FG interviews revealed that concepts and meanings linked to religion, religiosity, and secularization issues did not only appear at several points in the narrations but permeated the whole discussion. The interviewees made a clear link between a person's religiosity and a higher propensity to marry. In addition, the participants recognized Italy as a Catholic and religious setting, and they referred to the Catholic culture and tradition when they discussed cohabitation and marriage. Informants unanimously acknowledged that the Catholic religion is among the main reasons why cohabitation does not spread as quickly in Italy as elsewhere.

However, specific reference to Catholic precepts, dogmas, or sanctions was absent from all FG interviews. Although the influence of the Catholic Church permeates the setting of family choices in Italy, no one referred to the fact that cohabitation - a practice that openly acknowledges sexual relationships outside marriage - is forbidden by the Church. Thus, our findings speak to the possibility that the perception of religion's importance in individual choices does not act through an explicit attachment to precepts and dogmas.

Specific reference to the role of religion appeared in two clusters of participants: those who strongly supported Catholicism and those who were in open opposition to it. The former group, mainly formed of highly educated women, advocated that people decide to get married because - despite the increasing number of cohabitations perceived around them - they still believe in marriage as a foundation of society. As one informant stated, "I'm a religious person, so I believe in marriage, not in 
cohabitation" (FG2, woman, highly educated). They argued that a church wedding has a specific symbolic meaning: spouses declare their intention to get married before God, not only in the presence of a person responsible for administrative tasks. Among this group of participants the deeper meaning of the Christian message, only partly mediated by Catholicism, emerged. A man and a woman who decide to get married in a Catholic rite freely choose to consolidate their union before God, because they believe that God's grace will make their marriage fruitful and happy. One female informant put this clearly, "I married 10 years ago, when I was young ... I decided to get married in church because I am a practicing Catholic... the marriage has a value beyond a civil union." (FG2, woman, highly educated). Interestingly, the overall process of secularization seems to have made this group of 'deep believers' increasingly selective. Within this group some participants revealed that they are happy that cohabitation is now spreading rapidly in Italy, because in the future only those individuals who are genuinely religious will opt for marriage, in a conscious way. Importantly, even among this cluster of practicing Catholics, there were no specific references to Catholic precepts and dogmas.

At the other extreme, a connection between cohabitation and secularization was recurrently mentioned by a cluster of highly educated people (again, formed of individuals present across different FG interviews) who were extremely opposed to conventional social norms and the Church. The presence of a group of 'ideological cohabitors' has also been emphasized in other qualitative studies about cohabitation in Italy (Belletti, Boffi, and Pennati 2007; Grilli 2010). For this group, cohabiting means acting against the dominant morality in a public rejection of the institution of marriage. For instance, the following participants put this concept very clearly: "[cohabitation] is a personal, even ideological, cultural choice, because I don't like [the idea] of getting married" (FG2, woman, highly educated); "I reject the 'marriage system', and I do not want to help preserve it forever" (FG3, man, highly educated). For these higher educated participants, cohabitation means a strong form of commitment in itself that is perceived as at least as important as a traditional (religious) marriage. A highly educated woman stated that "...cohabitation is already per se a commitment. When my partner and I decided to start living together, for us it was like deciding to get married: it was exactly the same thing" (FG1, woman, highly educated). For this cluster of highly educated people, cohabitors work harder at the quality of the relationship, for example: "the advantage of cohabitation is this: you wake up in the morning and if you want to leave, you can leave, and so... you have to choose to stay" (FG4, man, highly educated).

In sum, some participants strongly supported Catholicism, others openly opposed it, the majority fell in between, and family life was discussed in the light of Catholic religion and in relation to it. However, the absence of specific reference to the teaching 
of the Catholic doctrine, or to the fact that cohabitation means "living in sin", suggests exploring the role of religion in people's family lives along other dimensions.

\subsection{Social pressure}

Our results highlight the presence of a marked social pressure to get married. Such pressure acts through two channels: the judgment of the family of origin and the opinions of "the others". The role of the family of origin is considered to be especially important, e.g., "...a religious person, who grew up in a family with religious values, may be more inclined to marry. And the family could push for a Church wedding" (FG5: W, high education). The parents tend to believe that their child is "really settled down" only if he/she is married, as one informant explicitly put it,

...if you are from a certain Catholic family, your parents might accept that you cohabit, but sooner or later you have to get married... you have to settle down. (FG4, man, highly educated)

The pressure is not explicit or strong, but some participants experienced such pressure during their early life course. The role of the family of origin in pushing for marriage is seen as a general latent factor, as the following female participant suggested: "I think that many couples marry because you have to get married [...] because it is something natural, something expected by the family" (FG1, woman, highly educated). Even if some informants say explicitly that their family did not exert any pressure on them, they acknowledge that in general this pressure exists. Children of religious parents may not want to embarrass them, create interpersonal conflicts, or incur negative parental sanctions. Marriage is something "expected" in the life of Catholic believers:

In principle, I think marriage originates from religion ... When you are a kid you grow up with the continuous presence of religion in the family, and later when you are an adult it is natural to get married: marrying becomes something expected because of the culture ... because of religion. (FG6, man, low educated)

The pressure to get married not only originates from the family of origin, but also from the social network in which people live. The participants repeatedly discussed the role of "the others" in an individual choice between cohabitation and marriage. Again, the pressure does not have a concrete form, but is important because "[M]arriage is 
something that you celebrate in front of the others" (FG5, woman, low educated). We learn that a cohabiting couple is not recognized "by the others" in the same way as a married couple is. According to one informant,

Despite everything, today two people who are married are considered as 'husband and wife'; two people cohabiting, although they live together for a long time, although they have a child, and as modern as we are, they are not $100 \%$ a couple to the others. (FG8, man, low educated)

Another informant said "when you cohabit you do not have the same role in society as you would if married" (FG7, woman, low educated). This perspective, brought to the extreme, transforms marriage into a sort of status symbol, where being a wife and a husband, likely a mother and a father, represents something that gives partners a higher social status - e.g., “...once married, you're a 'husband and wife', then perhaps also a 'mother'; when you cohabit you do not have the same role in society..." (FG5, woman, low educated). In another discussion, one informant explicitly said that marriage is strongly encouraged by society.

Many people get married just because society is asking them to do it; otherwise their relationship would not be well perceived by the others. (FG4, man, high educated)

In sum, religious individuals perceive marriage as a socially accepted behavior, which is approved by society, the family, and "relevant others" in their social surroundings. Consistent with the familistic interpretation of Italian family formation practices (Dalla Zuanna 2001; Rosina and Fraboni 2004; Di Giulio and Rosina 2007), the pressure to marry originated by the family of origin is seen as more relevant than the voices of "the others". One female respondent put this quite clearly: "In the decision to marry instead of cohabit, the family is much more important than friends" (FG2, woman, highly educated).

The social pressure to marry generated by the family of origin and the pressure from "the others" together creates the condition for a general social disapproval of cohabitation. Nonetheless, within this context the secularization process is at play. Coherent with the arguments presented so far, and despite the dominant principles of the Roman Catholic Church, the diffusion of cohabitation seems to be occurring exactly because cohabitation is increasingly accepted by friends and, especially, by parents. The following argument was brought up in all FG interviews, 
I think that today it is easier to start to cohabit simply because cohabitation is more socially accepted. (FG1, woman, highly educated)

\subsection{Tradition}

The Church wedding represents an important form of ritual, a crucial 'rite of passage' in the life of many Italians. It embodies the concept of tradition and symbolizes an acknowledgment of customs and habits. Our findings suggest that people are increasingly confronted with a choice between cohabiting and a Church wedding. Marrying in Church guarantees the continuation of tradition and is often associated with the "most beautiful day" in one's life. This kind of argument was mostly mentioned by women, irrespective of their education. For instance, one woman stated that "[marriage in church] is the most beautiful day of your life ... you choose the most beautiful flowers ... you choose the best restaurant ... you choose the most beautiful dress... In short: for the most beautiful day of your life you want everything to be perfect!" (FG5, woman, low educated).

Opting for a civil marriage clearly represents a secularized, public choice. When the partner is not a believer or belongs to another religion it is possible to celebrate a mixed rite. In the Canonic body of laws, a Church marriage is valid even if one of the partners is not Catholic. The main aspect differentiating religious and civil marriage is the quality and status of the ceremony. The religious ceremony is more pompous, but it also lends more importance to the day itself. A church is perceived as a "nicer location". On the other hand, a civil ceremony is not perceived as attractive or exciting, as for the following woman:

a civil ceremony is not very exciting ... a Church marriage is another story: there is more pathos! I think those who marry in Church because they are religious themselves are very few, they simply do it because of tradition (FG1, woman, highly educated)

The rituality of a Church wedding helps to preserve tradition. Also, for those who cohabit prior to marriage, such ritual is important. They start to live together without marrying in order to test the functionality of their relationship, but still plan marriage as the ultimate goal. For instance, one female informant declared: "I started to cohabit to test my relationship, but only with the idea of soon marrying in Church" (FG1, woman, highly educated). Interestingly, from this perspective marriage can be conceived more as a "rite of confirmation" than as a "rite of passage" (Saraceno 2012). 
For several participants, the decision to cohabit, or even the decision to marry in the town council, means "breaking with tradition". When a specific reference to the parents' desire for a Church wedding is made, generally the person's father is mentioned. Church weddings are preferred because "the real marriage is in church! For my father 'a contract' at the municipality has no meaning" (FG2, woman, highly educated). Another female informant stated: "I think that many people are marrying in Church because they think that otherwise their father would be disappointed" (FG1, woman, highly educated).

In the FG interviews a clear tendency among participants to associate "marriage" with a "church marriage" emerged. Interestingly, those who would like to reject marriage in order to oppose the prevailing morality, the group of ideological cohabitors', do not find civil marriage a suitable alternative to religious marriage, because it also represents a choice imposed by society. They think that only cohabiting represents a public rejection of the "marriage system".

To summarize, our findings reveal the importance of religion in family formation choices. However, for the most part this influence seems to act indirectly, through the channels of social pressure and tradition, and not through an explicit attachment to precepts and dogmas. The focus group participants suggest that the choice of marriage may represent more a tribute to tradition, parents' wishes, and social expectations which are strongly related to religiosity - rather than a conscious desire to adhere to religious precepts.

\subsection{Within-country idiosyncrasies}

Italy has marked regional differences in family formation practices (Kertzer et al. 2008). Our analysis considers only Florence, in Central Italy: since the 1980s the city has traditionally been governed by liberal left-wing parties that are relatively supportive of non-traditional living arrangements. Our findings seem to be in line with this openminded attitude towards new family practices. However, almost all FG interviews included participants with Southern Italian origins, providing us the opportunity to elicit differences across regions. Our research corroborates previous qualitative and quantitative findings regarding the deep socio-demographic differences between Italian regions (Kertzer et al. 2008; Löffler 2009; Salvini and De Rose 2011), suggesting that the link between religion and family formation choices is mediated by the regional setting (see also Garelli 2011). The participants constantly referred to the South-North division, saying that the role of religion is more powerful in the southern regions of the country because the South is simply more religious and more attached to traditional values. Also, the pressure people feel from family and society to get married rather than 
cohabit seems to be exacerbated in Southern Italy. However, exploring in greater detail how the regional context mediates opinions and attitudes towards marriage and cohabitation is beyond the scope of this paper.

\section{Results: Legal framework and union formation choices}

A secondary objective of our investigation is to explore the link between family formation and the legal regulation of marriage and divorce, which has been extensively shaped by the Roman Catholic Church. Although the FG guidelines did not explicitly ask about fears of the cost of divorce, the topic appeared spontaneously in all groups. Divorce in Italy seems to incur economic and psychological costs, as well as taking time. Deciding to dissolve an unhappy marriage implies being ready to afford economic and psychological costs due to the many formalities and technicalities. In addition, if spouses disagree and/or have children, the time required to legally separate can be much longer. Statements such as the following were present in nearly all FG interviews, "... if you are married, divorce essentially means many psychological costs, many legal strains, especially if you have children..." (FG4, man, highly educated). As a consequence, at several points in the discussions the participants said that one of the major advantages of cohabitation over marriage is that cohabitating relationships are easier to terminate: "Cohabitation has an advantage in case of separation: if you cohabit everything is simpler because it does not incur many technicalities" (FG8, man, low educated), "Divorce is a complex, long, and expensive thing. So, although the couple is unhappy, you may be forced to remain together. By contrast, putting an end to a cohabiting union is much faster" (FG2, woman, highly educated).

On the other hand, informants also acknowledged the legal disadvantages of cohabitation. Being unmarried was seen as "having almost no type of protection". For instance, participants were aware that unmarried individuals are not entitled to draw benefits, such as the partner's old age pension, upon death. Many participants also mentioned that, if they died, their belongings, such as savings or property, would become the property of their family of origin and not of their partners. Further, additional voices worried about regulations in the event of illness. They especially feared situations in which one partner might be seriously ill: they feared not being recognized as a family member.

In the Italian public and political debate these legal disadvantages of cohabitation are challenged by the increasing public demand to extend to cohabitation the rights and the obligations that are regulated within marriage. However, the question is, when nonbelieving heterosexual partners have the possibility of formalizing their union through a civil marriage and could simply get married, why are they asking for additional rights 
for cohabiting partners? This question emerged spontaneously from the interaction between participants in nearly all the meetings; for instance,

If you ask for the legalization of consensual unions, why don't you simply get married? It is not a matter of religion, because 'civil marriage' does exist, I mean: you can marry in the town council instead of the Church. (FG2, woman, highly educated)

This question is also quite common in Italian political debate, because it is the major argument of those who are against extending partners' rights to cohabiting couples. Our qualitative investigation shed light on this hot topic. The replies were always the same and can be divided into two groups. The majority of people reacted by saying that they would prefer to cohabit instead of having a civil marriage because in the case of divorce, given the adverse Italian legal setting, they would likely experience many legal and economic problems. The second group consisted of a select group of highly educated informants, 'ideological cohabitors' who openly opposed marriage as an institution, who argued that no matter if a marriage is celebrated with a religious or civil ceremony, it has a symbolic meaning that people should be free to reject. To the best of our knowledge, this is the first time that this topic has been clearly systematized with these two motivations distinctly emerging.

Finally, in 6 out of 8 groups there was a spontaneous discussion regarding the legal rights of same-sex couples compared to heterosexual couples. Participants argued for the public recognition of same-sex couples, because they cannot be seen as "second class" citizens compared to heterosexual couples who belong to the "first class". Heterosexual couples that would like to formally legalize their unions are entitled to get married, likely celebrating a civil ceremony if they are not true believers. However, homosexual couples have no choice but to cohabit without the possibility of legally regulating their rights as partners (e.g., inheritance, pension benefits, visitation rights). One male participant stated: "I think that some forms of protection [for cohabiting couples] are required, because otherwise one neglects a whole world of emotional relationships that concerns homosexual couples that are not entitled to marry" (FG3, man, high education).

Overall, FG participants in Florence perceived a whole spectrum of legal disadvantages of cohabitation compared to marriage. In addition, the participants pointed out that although same-sex couples are today increasingly accepted, the State has failed to adjust to this on-going change. Whether the attitudes we revealed for the city of Florence are representative of other Italian realities is unknown. 


\section{Summary and discussion}

For much of Italy's history, the institutions of marriage and religion have been closely related (Ercolessi 2009). There is a general consensus among Italian demographers and sociologists that religious attendance and belief are positively associated with marriage. However, we know little about how religion prevents the diffusion of cohabitation, because it is still unclear in which dimensions religion and family choices intertwine the most. Investigating FG discussions illuminates some of the nuances of how people experience religion and draw upon it when making family choices. Our findings suggest that in Italy the Roman Catholic Church maintains a strong influence in shaping family formation patterns in favor of marriage. In this respect, at least three key findings emerge from our study.

First, despite the principles of the Roman Catholic Church declaring marriage to be a sacrament and prescribing that sexual relations should only occur within a marriage and that artificial means of contraception are forbidden, no single reference to the fact that cohabitation means 'living in sin' appeared in the discussions. Essentially, two select groups formed of highly educated individuals made explicit references to Catholicism: the group of 'ideological cohabitors' and the group of 'deep believers'. For the former group, the choice to cohabit represents an important public rejection of the institution of marriage. For the latter, marriage has a symbolic meaning, and has a value that goes beyond a simple civil union. In general, our findings can be read as in line with those who talk about "religious bricolage" (Garelli, Guizzardi, and Pace 2003; Caltabiano, Dalla Zuanna, and Rosina 2006), referring to the majority of people who maintain a relation with the transcendent, form an independent sense of religiosity, and are flexible about accepting or refusing specific dogmas (see also Garelli 2011; Bonarini 2013). In sum, the influence of the Catholic Church permeates the setting of family choices in Italy, but our findings reveal the possibility that the perception of religion's importance in individual choices mainly acts indirectly, and not through an explicit attachment to precepts and dogmas.

Instead, we found strong pressure in favor of marriage coming from the family of origin and society in general. The informants discussed the perception of social disapproval of cohabitation, including a lack of social recognition and possible stigmatization by "the others." In addition, the family of origin perceives that their child is 'really settled down' only if he/she is married. The pressure is not explicit and strong, but it is felt. This finding supports the argument of a link between strong family ties and the lack of development of cohabitation (Rosina and Fraboni 2004; Di Giulio and Rosina 2007; Schröder 2008). Since parents tend to discourage their offspring from non-normative behaviors (such as cohabitation), their adult children are confronted with strong pressure when making their own choices. In the diffusion of modern cohabitation 
in Italy the influence of older generations is thus crucial (see also Belletti, Boffo, and Pennati 2007; Grilli 2010). Our findings suggest that the secularization process especially involves the younger generations, who will soon become parents and are less likely to pressure their own children to marry (Rosina and Fraboni 2004; Di Giulio and Rosina 2007). Thus, cohabitation will increasingly spread through Italian society according to a vertical diffusion of family behaviors.

Third, the role of tradition seems to be central in people's family choices. The popular choice of a religious marriage reveals a strong persistence of attitudes and behaviors that are close to religious precepts (Caltabiano, Dalla Zuanna, and Rosina 2006). However, in many cases this choice seems to represent more a form of ritual, an acknowledgment of tradition and habits, rather than representing a conscious consequence of specific religious choices. Many people opt for marriage because they would like to preserve age-old traditions rather than because they attach importance to Catholic precepts.

An additional finding of this research is that the status of cohabitation is unanimously recognized as having strong legal disadvantages. Partners' rights are a serious problem. There might be problems with hospital visits and getting specific information on a partner's condition, especially if the partner is in a critical condition, as well as with inheritance. Therefore several participants considered marriage as more attractive than cohabitation specifically for this reason. The lack of legal recognition of cohabitors' rights is perceived as unfair and unjust, especially among those who do not recognize themselves in the 'dominant thinking' of society and the Church. Thus, we provide qualitative evidence on the divergence that exists between the lack of state laws regarding consensual unions, and the acceptance of cohabitation on an individual basis.

Another specific feature of Italian society is embedded in the relatively complex legal procedure that is required to obtain a divorce. Our analysis has shown that this complicated procedure, originally intended to discourage marriage dissolution, seems to have resulted in the opposite effect. One reason young adults opt for cohabitation is to avoid the difficulties of terminating an unhappy marriage. Many participants expressed a desire for the law to be modified to make divorce easier and quicker, recognizing the ongoing new Italian family dynamics. Thus, a simplification of the present law might, ironically, encourage entry into marriage. The role of divorce legislation as an inhibitor of marriage needs to be further explored in the future (qualitative and quantitative) research. Currently, a new law proposing a "short divorce" is being under discussion in the Italian Parliament; it has been approved by the Low Chamber and will be discussed in the Senate in Autumn 2014.

To conclude, it is important to note that the attitudes we found for the city of Florence may not be generalizable to other Italian realities. Previous qualitative research (Schröder 2008; Löffler 2009) focusing on Bologna (Emilia-Romagna region) 
and Cagliari (Sardinia region) revealed at least two different settings for family formation practices. The Centre-North (exemplified by the city of Bologna) is characterized by less traditional attitudes towards new union formation practices, while the South and Islands (represented by the city of Cagliari) are much more traditional. The population living in the city of Florence - and Tuscany, in general - is quite secular, and this can affect informants' answers. However, our findings are in line with the view expressed by other scholars regarding the relatively flexible attitudes of Italians towards sexuality and contraception with respect to Catholic doctrine (Dalla Zuanna, De Rose, and Racioppi 2005; Caltabiano, Dalla Zuanna, and Rosina 2006; Barbagli, Dalla Zuanna, and Garelli 2010). We showed that the widely prevailing pressure of parents and peers and the hedonistic aspects of the traditional Church wedding are much more important in partnership formation and way of living as a couple than Catholic prescripts. Thus, we posit that the direct effect of religion on individual choices is overestimated when interpreting the Italian family.

\section{Acknowledgments}

This research was funded by Brienna Perelli-Harris's ERC CHILDCOHAB starting grant during the period 2011-2013. The article benefited from discussions with Focus on Partnership team members during workshops, as well as revisions suggested by Brienna Perelli-Harris and other team members. We are also grateful to two anonymous reviewers of this journal whose valuable comments and suggestions greatly improved this manuscript. Monika Mynarska is gratefully acknowledged for constant support and advice. 


\section{References}

Adsera, A. (2006). Marital Fertility and Religion in Spain, 1985 and 1999. Population Studies 60(2): 205-221. doi:10.1080/00324720600684817.

Angeli, A., Pillati, M., and Rettaroli, R. (1999). Opinioni e intenzioni di vita di coppia riproduzione. In: De Sandre, P., Pinnelli, A., and Santini, A. (eds.). Nuzialità e fecondità in trasformazione: percorsi e fattori del cambiamento. Bologna: Il Mulino: 365-378.

Baranowska-Rataj, A., Mynarska, M., and Vignoli, D. (2013). A Dirty Look From The Neighbors. Does Living In A Religious Neighborhood Prevent Cohabitation?. Paper presented at the 2013 Population Association of America Annual Meeting, New Orleans (U.S.), April 11-13 2013.

Barbagli, M. (2000). Sotto lo stesso tetto. Mutamenti della famiglia in Italia dal XV al XX secolo. Bologna: Il Mulino.

Barbagli, M. and Saraceno, C. (eds.) (1997). Lo stato delle famiglie in Italia. Bologna: Il Mulino.

Barbagli, M., Castiglioni, M., and Dalla Zuanna, G. (2003). Fare famiglia in Italia. Un secolo di cambiamenti. Bologna: Il Mulino.

Barbagli, M., Dalla Zuanna, G., and Garelli, F. (2010). La sessualità degli italiani. Bologna: Il Mulino.

Belletti, F., Boffi, P., and Pennati, A. (2007). Convivenze all'Italiana. Motivazioni, caratteristiche e vita quotidiana delle coppie di fatto. Milano: Paoline Editoriale Libri.

Berghammer, C. (2009). Religious Socialisation and Fertility: Transition to Third Birth in The Netherlands. European Journal of Population 25(3): 297-324. doi:10.10 07/s10680-009-9185-y.

Berghammer, C. (2012). Family Life Trajectories and Religiosity in Austria. European Sociological Review 28(1): 127-144. doi:10.1093/esr/jcq052.

Bonarini, F. (2013). I comportamenti religiosi in Italia: una nuova lettura dei dati ufficiali. Religioni e Società - Rivista di scienze sociali della religione XXVIII(77): 33-54.

Caltabiano, M., Dalla Zuanna, G., and Rosina A. (2006). Interdependence between sexual debut and church attendance in Italy. Demographic Research 14(19): 453-484. doi:10.4054/DemRes.2006.14.19. 
Castiglioni, M. (1999). Analisi differenziale della nuzialità. In: De Sandre, P., Pinnelli, A., and Santini A. (eds.). Nuzialità e fecondità in trasformazione: percorsi e fattori del cambiamento. Bologna: Il Mulino. 347-363.

Dalla Zuanna, G. (2001). The banquet of Aeolus: a familistic interpretation of Italy's lowest low fertility. Demographic Research 4(5): 133-164. doi:10.4054/Dem Res.2001.4.5.

Dalla Zuanna, G. and Micheli, G.A. (2004). Strong Family and Low Fertility: A Paradox? Dordrecht, Boston, London: Kluwer Academic Publisher.

Dalla Zuanna, G., De Rose A., and Racioppi, F. (2005). Low fertility and limited diffusion of modern contraception in Italy during the second half of the twentieth Century. Journal of Population Research 22(1): 21-48. doi:10.1007/ BF03031802.

De Rose, A. and Marquette, C. (2011). Same-sex families in Italy compared to Spain. Journal of Family Research 7: 53-69.

De Rose, A., Racioppi, F., and Zanatta, A.L. (2008). Italy: Delayed adaptation of social institutions to changes in family behaviour. Demographic Research S7(19): 665-704. doi:10.4054/DemRes.2008.19.19.

De Rose, A. and Vignoli, D. (2011). Families all'italiana: 150 years of history. Rivista Italiana di Demografia, Economia e Statistica LXV(2): 121-144.

De Sandre, P., Ongaro, F., Rettaroli, R., and Salvini, S. (1997). Matrimonio e figli: tra rinvio e rinuncia. Bologna: Il Mulino.

De Santis, G., Maltagliati, M., and Salvini, S. (2014). How close? An attempt at measuring the cultural distance between countries. Working Papers No. 38 / 2014, Institute of Statistics and Demography, Warsaw School of Economics.

Di Giulio, P. and Rosina, A. (2007). Intergenerational family ties and the diffusion of cohabitation in Italy. Demographic Research 16(14): 441-468. doi:10.4054/ DemRes.2007.16.14.

Dittgen, A. (1995). The form of marriage in Europe: Civil ceremony, religious ceremony, survey and trends. Population 7: 95-123.

Ellingson, S., Tebbe, N., Van Haitsma, M., and Laumann, E.O. (2001). Religion and the politics of sexuality. Journal of Contemporary Ethnography 30(1): 3-55. doi:10.1177/089124101030001001. 
Esping-Andersen, G. (1990). The Three Worlds of Welfare Capitalism. Cambridge: Polity Press.

Ercolessi, G. (2009). Italy: The Contemporary Condition of Italian Laicità. In: Kosmin, B.A. and Keysar, A. (eds.). Secularism, Women \& the State: The Mediterranean World in the $21^{\text {st }}$ Century. Hartford: Institute for the Study of Secularism in Society and Culture: 9-28.

Frejka, T. and Westoff, C.F. (2008). Religion, Religiousness and Fertility in the US and in Europe. European Journal of Population 24(1): 5-31. doi:10.1007/s10680007-9121-y.

Gabrielli, G. and Hoem, J.M. (2010). Italy's non-negligible cohabitational unions. European Journal of Population 26(1): 33-46. doi:10.1007/s10680-009-9193-y.

Gabrielli, G. and Vignoli, D. (2013). The Breaking-Down of Marriage in Italy: Trends and Trendsetters. Population Review 52(1): 87-109.

Garelli, F. (2011). Religione all'italiana. L'anima del paese messa a nudo. Bologna: Il Mulino.

Garelli, F., Guizzardi, G., and Pace, E. (eds.) (2003). Un singolare pluralismo. Bologna: Il Mulino.

Giddens, A. (1994). Living in a Post-Traditional Society. Reflexive modernization: politics, tradition and aesthetics in the modern social order. Stanford University Press.

Gorski, P.S. and Altınordu, A. (2008). After secularization? Annual Review of Sociology 34(1): 55-85. doi:10.1146/annurev.soc.34.040507.134740.

Goldscheider, C. (2006). Religion, family, and fertility: What do we know historically and comparatively? In: Derosas, R. and van Poppel, F. (eds.). Religion and the decline of fertility in the western world. Dordrecht: Springer: 41-57. doi:10.10 07/1-4020-5190-5_3.

Grilli, S. (2010). Famiglie senza matrimonio. Informalità delle relazioni e continuità parentale in area senese. In: Grilli, S. and Zanotelli, F. (eds.). Scelte di famiglia. Tendenze della parentela nella società contemporanea. Pisa: ETS Edizioni.

Impicciatore, R. and Billari, F.C. (2012). Secularization, Union Formation Practices, and Marital Stability: Evidence from Italy. European Journal of Population 28(2): 119-138. doi:10.1007/s10680-012-9255-4.

International Social Survey Program (2008). The ISSP. www.gesis.org/en/issp/ 
Istat (2011). Come cambiano le forme familiari. www.istat.it.

Kalmijn, M. (2004). Marriage rituals as reinforcers of role transitions: An analysis of weddings in the Netherlands. Journal of Marriage and Family 66(3): 582-594. doi:10.1111/j.0022-2445.2004.00039.x.

Kertzer, D.I., White, M.J., Bernardi, L., and Gabrielli, G. (2008). Italy's path to very low fertility. The adequacy of economic and Second Demographic Transition theories. European Journal of Population 25(1): 89-115. doi:10.1007/s10680008-9159-5.

Kosmin, B.A. (2009). France, Italy and Spain: Political Secularism and Public Opinion. In: Kosmin, B.A. and Keysar, A. (eds.). Secularism, Women \& the State: The Mediterranean World in the $21^{\text {st }}$ Century. Hartford: Institute for the Study of Secularism in Society and Culture: 29-40.

Kosmin, B.A. and Keysar, A. (eds.) (2009). Secularism, Women \& the State: The Mediterranean World in the $21^{\text {st }}$ Century. Hartford: Institute for the Study of Secularism in Society and Culture.

Lehrer, E.L. (2000). Religion as a determinant of entry into cohabitation and marriage. In: Waite, L., Bachrach, C., Hindin, M., Thomson, E., and Thornton, A. (eds.). The ties that bind: Perspectives on marriage and cohabitation. Hawthorne: Aldine de Gruyter: 227-252.

Lesthaeghe, R.J. and Surkyn, J. (1988). Cultural dynamics and economic theories of fertility change. Population and Development Review 14(1): 1-45. doi:10.2307/ 1972499.

Lesthaeghe, R.J. and Neidert, L. (2006). The Second Demographic Transition in the United States: Exception or textbook example? Population and Development Review 32(4): 669-698. doi:10.1111/j.1728-4457.2006.00146.x.

Liefbroer, A.C. and de Jong Gierveld, J. (1993). The impact of rational considerations and perceived opinions on young adults' union formation intentions. Journal of Family Issues 14(2): 213-235. doi:10.1177/019251393014002004.

Livi Bacci, M. (2001). Too few children and too much family. Daedalus 130(3): 139156.

Löffler, C. (2009). Non-Marital Cohabitation in Italy. [Ph.D. Thesis]. Rostock: Universität Rostock.

McQuillan, K. (2004). When Does Religion Influence Fertility? Population and Development Review 30(1): 25-56. doi:10.1111/j.1728-4457.2004.00002.x. 
Oropesa, R.S. (1996). Normative beliefs about marriage and cohabitation: A comparison of non-Latino whites, Mexican Americans and Puerto Ricans. Journal of Marriage and the Family 58(1): 49-62. doi:10.2307/353376.

Perelli-Harris, B., Mynarska, M., Berrington, A., Evans, A., Berghammer, C., Isupova, O., Keizer, R., Klärner, A., Lappegård, T., and Vignoli, D. (2014). Towards a new understanding of cohabitation: Insights from focus group research across Europe and Australia. Demographic Research 31(34): 1043-1078. doi:10.4054/DemRes.2014.31.34.

Philipov, D. and Berghammer, C. (2007). Religion and fertility ideals, intentions and behaviour: A comparative study of European countries. Vienna Yearbook of Population Research 2007: 271-305. doi:10.1553/populationyearbook2007s271.

Pierucci, A.F. and Prandi, R. (2000). Religious Diversity in Brasil: Numbers and Perspectives in a Sociological Evaluation. International Sociology 15(4): 629639. doi:10.1177/0268580900015004004.

Reher, D.S. (1998). Family Ties in western Europe: Persistent Contrasts. Population and Development Review 24(2): 203-234. doi:10.2307/2807972.

Rosina, A. and Fraboni, R. (2004). Is marriage losing its centrality in Italy? Demographic Research 11(6): 149-172. doi:10.4054/DemRes.2004.11.6.

Salvini, S. and De Rose, A. (eds.) (2011). Rapporto sulla popolazione. L'Italia a 150 anni dall'Unità. Bologna: Il Mulino.

Sansonetti, S. (2009). Social Indicators of Secularisation in Italy. In: Kosmin, B.A. and Keysar, A. (eds.). Secularism, Women \& the State: The Mediterranean World in the $21^{\text {st }}$ Century. Hartford: Institute for the Study of Secularism in Society and Culture: $137-154$.

Saraceno, C. (2012). Coppie e famiglie. Non è questione di natura. Milano: Feltrinelli Editore.

Schröder, C. (2008). The influence of parents on cohabitation in Italy: Insights from two regional contexts. Demographic Research 19(48): 1693-1726. doi:10.4054/ DemRes.2008.19.48.

Sigalow, E., Shain, M., and Bergey, M.R. (2012). Religion and Decision about Marriage, Residence, Occupation, and Children. Journal for the Scientific Study of Religion 51(2): 304-323. doi:10.1111/j.1468-5906.2012.01641.x. 
Smith, C. (2003). Theorizing Religious Effects among American Adolescents. Journal for the Scientific Study of Religion 42(1): 17-30. doi:10.1111/1468-5906.t01-100158 .

Sweet, J.A. and Bumpass, L.L. (1990). Religious Differentials in Marriage Behavior and Attitudes. NSFH Working Paper no. 15. University of Wisconsin, Center for Demography and Ecology.

Tanfer, K. (1987). Patterns of Premarital Cohabitation among Never-Married Women in the United States. Journal of Marriage and the Family 49(3): 483-97. doi:10.2307/352194.

Teachman, J.D. (2002). Stability across cohorts in divorce risk factors. Demography 39(2): 331-352. doi:10.1353/dem.2002.0019.

Thornton, A. and Camburn, D. (1987). The Influence of the Family on Premarital Sexual Attitudes and Behavior. Demography 24(3): 323-40. doi:10.2307/ 2061301.

Thornton, A., Axinn, W.G., and Hill, D.H. (1992). Reciprocal Effects of Religiosity, Cohabitation, and Marriage. American Journal of Sociology 98(3): 628-651 doi:10.1086/230051.

van de Kaa, D. (1987). Europe's second demographic transition. Population Bulletin 42(1): $1-57$.

Vignoli, D., Gabrielli, G., and Gualtieri, G. (2011). Formazione e scioglimento delle unioni. In: Salvini, S. and De Rose, A. (eds.). Rapporto sulla popolazione. L'Italia a 150 anni dall'Unità. Bologna: Il Mulino.

Zanatta, A.L. (2008). Le nuove famiglie. Bologna: Il Mulino. 
Vignoli \& Salvini: Religion and union formation in Italy: Catholic precepts, social pressure, and tradition 